\title{
Study on Effective Path of Ideological and Political Education for College Students in New Era
}

\author{
Hongzhi Liu \\ College of Engineering, Bohai University, Jinzhou Liaoning, 121000, China
}

Keywords: new era; college students; ideological and political education work

\begin{abstract}
The college period is an important stage in the shaping of students' outlook on life and values, and is the most important stage for preparing for the society. In the new era, the requirements for talents include not only skills, but also quality level as an important standard. Therefore, it is necessary to continuously explore new-type guiding paths of ideological and political education suitable for contemporary development to cultivate more comprehensive talents for the social development.
\end{abstract}

At present, the educational thought of "People Orientation, Moral Education First" has been paid more and more attention, which is also an important content for implementing guidelines of the party to strengthen ideological and political education and cultivate social talents with all-round development of morality, intelligence, physique and aesthetics. In actual education, it is essential to hold the realistic and pragmatic spirit, explore development characteristics of contemporary college students, combine the requirements of the reality, and conclude advanced guiding thinking on ideology and politics to encourage college students to form benign values and more clear understanding of their responsibilities and mission.

\section{Characteristics of College Students in New Era}

Most college students of post-90s generation are basically only children, a different generation, and they usually show some characteristics. On the one hand, they prefer to advocate individual character and self, like weird matters, and they have stronger subversive desires than $70 \mathrm{~s}$ and $80 \mathrm{~s}$; on the other hand, they are more forward-looking and innovative, like to enjoy a happy life, pursue a different way of life, and not easily give up their pursuit of life because of the influence of others; and they follow the trend and focus on life tastes, both rational and helpless, and both rebellious, tolerant and pluralistic. In general, college students in the new era are a group of young people with diversified mindsets, open behaviors, individuality, adventurousness, and self-consciousness.

\section{Current Ideological Condition of Contemporary College Students}

\subsection{The increasingly positive three views and existing utilitarianism}

The investigations show that most of college students in the new era have expressed their willingness to "work for the best ideal of humanity - communism for a lifetime" and hope "to make more contributions to society"; "to seek for their own interests when contributing to the motherland and society"; they think that people should be "not afraid of hardships and keep forging ahead" when alive; "It is the best embodiment of realizing its own value to do something meaningful for the society", and "the value of everyone shall be fully respected while contributing its own power for the society". It can be seen that the life views of college students in new era are relatively positive, which perfectly realizes the organic integration of individual value and social value. And it can also indicate that some effects have been achieved in the cultivation of "three views" of college students by ideological and political education in colleges and universities in China in recent years. However, there still remains utilitarianism in some college students, only advocating egocentrism, lacking the dedication spirit to serve the people, putting individual interests in the first place, 
ignoring collective interests, lost in individualism, and losing their "spiritual soul” in excessively pursuit of material satisfication.

\subsection{The in-place cognition and non-uniform behavior}

The investigation shows that $94 \%$ of college students believe that people shall hold the principle of "mutual respect, mutual understanding and mutual help" in interpersonal relationships, which also indicates that the cognition of college students is suitable for social norm with correct value of right and wrong. However, there are still misconduct behaviors in many students and serious disconnection of ideological understanding from behaviors. For instance, many college students wish to establish a harmonious and stable social order, whereas, they are not willing to be constrained by relevant systems.

\subsection{The relatively stronger patriotism}

According to the survey, more than $96 \%$ of college students think that they will generate a sense of holiness and pride when singing national anthem, show strong patriotism in matters on national sovereignty and dignity and will protect national honor with practical actions, which also an important manifestation of the patriotism of college students.

\section{Effective Paths of Ideological and Political Education for College Students in New Era}

Based on current development condition of ideological concepts of college students, certain achievements have been obtained in ideological and political education, however, there are still utilitarianism, and the non-unified cognition and behavior. Therefore, it is necessary to fully combine characteristics of students, take effective methods and make innovations continuously. Based on actual work experience, effective paths to enhance ideological and political education of college students in new era are analyzed in detail.

\subsection{To hold educational concept of comprehensive cultivation}

The more effective ideological and political education of college students requires external coordination from comprehensive cultivation by colleges and universities, society and family, also requires internal coordination from the establishment of executive team, education team and management team. Different from external coordination, it is necessary for the internal system construction of ideological and political education to have a clear position about itself to give full play to its core function, and establish a Trinitarian cultivation system of executive team, management team and teaching team. For instance, instructor shall have a clear orientation as principal manager of ideological education, conduct effective management and guidance as core power of ideological and political education, and learn to form benign relations between teachers and students as mentor of their growth.

\subsection{To guide college students to resist decadent ideas in respecting the differences and tolerating the diversity}

Problems in recent years of national development, including violent earthquakes in many places and earthquake relief work with concerted efforts of global Chinese people, indicate the importance of traditional ideological and political education in China and imperceptible role in people's behaviors.

Whereas, it is still essential for us to reflect on the lack of better understanding of post-90s before major events. One of important reasons is the insufficient attention to the difference in the guidance of socialism core values on college students, and the lacking tolerance of diversities of students and the narrow paths.

Therefore, it is necessary to strengthen the understanding of college students in new era, seek for more effective paths and make full use of socialism core value system to realize the effective guidance of college students. First of all, network resources can be fully applied to build a campus website with ideology, enjoyment and services, and hold the initiative of network ideological and 
political education in hands without deliberately ignoring problems and contradictions in the development of college students; secondly, more social practice activities shall be organized and conducted to become an important part of teaching plan and credit assessment, and ideological and political education can be more institutionalized and standardized. And morality, intelligence, physique, aesthetics and labor shall be combined together to fully integrate education and cultural practical activities.

\subsection{To exert the dominant role and integrate ideological and political education and cultural knowledge}

Cultural knowledge and value guidance shall be closely related, with the function of cultivation of each subject, which is also the mission of all teachers. It is necessary to strengthen the construction of teaching material and teaching staff in the guidance of ideological and political education, choose more significant teaching content, improve teaching methods, make use of advanced teaching means to increase the appeal and attraction of ideological and political courses, give full play to the role of ideological and political education in philosophy and social science, find the key point, elaborately compile teaching material and establish a social science system with Chinese characteristics and Chinese manner. In fact, each subject contains rich ideological and political education resources. Teachers of each subject shall cooperate together to deeply explore human civilization achievements, national spirit, essence of things, moral sentiments and etc. In this way, students can obtain the influence of ideology and politics while learning knowledge.

\subsection{To help students solve practical problems and conduct well ideological and political educational work}

The ideological and political education of college students is actually the ideological work on human. The process of ideological and political education shall bring out the facts and reasons, convince people by reasoning, handle concrete affairs in a down-to-earth manner, and care about and touch human with emotion. For students from impoverished families, colleges and universities shall provide a reassuring learning environment to ensure that they can accomplish their study successfully; conduct the employment guidance of graduates to provide a direction for their future; perform guidance, management and appropriate and targeted psychological counseling to help them better solve problems in life and study in addition to satisfy their basic life requirements.

\subsection{To give full play to the role of organizations to enhance the appeal of ideological and political education}

Grassroots Party and Youth League organizations with wide coverage and perfect system and student organizations are the major advantage of ideological and political education of college students in new era, which shall be fully applied to construct Party branch in class to become the fundamental base for ideological and political education, and provide more comprehensive and in-place services for students' growth by virtue of the advantages in students cooperation and relation of Youth League organizations, student union and other student organizations. The construction of class collective shall be strengthened to help students to realize self-education and self-management with the cooperation of student community, student dormitory and campus network to give full play to its role in ideological and political education of college students.

\subsection{To strengthen the construction of teaching staff and improve the personnel quality and} competence.

The teaching staff with strong quality shall be established first to conduct well the ideological and political education for college students, form the construction of cadres of Party and government, teachers in ideological and political course and psychology and social science course, instructors and teachers in charge of class, like selecting academic backbones, and relevant incentive and safeguard mechanism shall be improved to build a good environment and a powerful development platform for personnel of ideological and political education. 


\section{Conclusion}

In conclusion, ideological and political education is a key educational content in college, and has an important influence on the future development of students. Based on current development status of college students, it is necessary to combine characteristics of students, establish a targeted educational mode, and incessantly explore more effective education path to improve knowledge skills and ideological quality of students.

\section{References}

[1] Wang Shijing. A Methodological Study on the Reform and Innovation of Ideological and Political Education for College Students in the New Era - The Dimension of "Things" "Time" and “Situation” [J]. Teaching and Research, 2018(02):107-112.

[2] Wang Hejia. Deficiency and Construction of Ideological and Political Education for College Students in Period of Social Transition [A]. The Founding Congress of Fujian Provincial University Counselor Specialized Committee \& Collection of Excellent Paper of the Further Improvement in Ideological and Political Education for College Students Forum [C], 2008:6.

[3] Li Weisheng. Ideological and Political Work for College Students in Network Era: Challenge and Countermeasures [A]. Collected Papers of "Long-distance Open Education" Seminar of Shandong Distance Education Society [C]. Shandong Distance Education Society, 2004:6.

[4] Li Weidong. On the Role of Emotional Education in Physical Education of Junior Middle Schools [J]. Contemporary Education Research and Teaching Practice, 2017(09):63. 